\title{
PENGARUH PROSES PENGELASAN PEDA BAJA KARBON RENDAH TERHADAP KEKUATAN TARIK
}

\author{
Arif Feriansah \\ Program StudiTeknik Mesin, Universitas Muhammadiyah Pekajangan Pekalongan \\ Jl. Raya Pahlawan No. 10 Kajen - Kab.Pekalongan \\ Email :arifferiansah8@gmail.com
}

\begin{abstract}
Abstrak
Pada masa sekarang, las SMAW banyak di pergunakan dalam dunia kontruksi contohnya seperti pengelasan plat-plat pada kapal dan pengelasan baja ringan seperti pembuatan rangka gedung. Tujuan penelitian ini adalah mengetahui pengaruh kekuatan tarik terhadap lasan pada baja karbon rendah setelah proses pengelasan. Metode penelitian yang digunakan adalah metode eksperimen. Penelitian ini menggunakan bahan plat baja karbon rendah, jenis las yang dipilih SMAW dengan tegangan 220 volt, kuat arus 110 amper, 120 amper dan 130 amper posisi pengelasan face to face, dengan elektroda E 6013, dimana akan dilakukan pembentukan variasi arus dengan bentuk kampuh $\mathrm{V}$ pada baja karbon rendah dengan ketebalan $10 \mathrm{~mm}$, kemudian dilakukan proses pengelasan $S M A W$ dan dilakukan pengujian tarik. Nilai rata-rata dari pengujian tarik tertinggi terdapat pada arus 130 amper dengan nilai sebesar 415,17 N/mm².
\end{abstract}

Kata Kunci: Baja Karbon Rendah, Pengelasan, Arus, Uji Kekuatan Tarik.

\begin{abstract}
Abstrak
One of the ways to At the present time, SMAW welding is widely used in the construction world, for example, such as welding plates on ships and welding light steel such as making building frames. The purpose of this study was to determine the effect of tensile strength and hardness on low carbon steel welds after the welding process. The research method used is the experimental method. This study uses a low carbon steel plate material, the type of welding chosen by SMAW with a voltage of 220 volts, a current strength of 110 amperes, 120 amperes and 130 amperes face to face welding position, with electrode $\mathrm{E} 6013$, where the formation of current variations with the $\mathrm{V}$ seam shape will be carried out. on low carbon steel with a thickness of $10 \mathrm{~mm}$, then the SMAW welding process is carried out and the tensile and hardness testing is carried out. The average value of the highest tensile test is at a current of 130 amperes with a value of $415.17 \mathrm{~N} / \mathrm{mm}^{2}$
\end{abstract}

Keywords: Low Carbon Steel, Welding, Flow, Tensile Strength Test.

PENDAHULUAN

Pengembangan teknologi di bidang konstruksi yang semakin maju tidak dapat dipisahkan dari pengelasan karena mempunyai peranan penting dalam rekayasa dan reparasi logam. Pembangunan konstruksi dengan logam pada masa sekarang ini banyak melibatkan unsur pengelasan khususnya bidang rancang bangun karena sambungan las merupakan salah satu pembuatan sambungan yang secara teknis memerlukan ketrampilan yang tinggi bagi pengelasnya agar diperoleh 
sambungan dengan kualitas baik. Lingkup penggunaan teknik pengelasan dalam konstruksi sangat luas meliputi perkapalan, jembatan, rangka baja, bejana tekan, sarana transportasi, rel, pipa saluran dan lain sebagainya ${ }^{1}$.

Faktor yang mempengaruhi las adalah prosedur pengelasan yaitu suatu perencanaan untuk pelaksanaan tugas akhir yang meliputi cara pembuatan konstruksi las yang sesuai rencana dan spesifikasi dengan menentukan semua hal yang diperlukan dalam pelaksanaan tersebut. Faktor produksi pengelasan adalah jadwal pembuatan, proses pembuatan, alat dan bahan yang diperlukan, urutan pelaksanaan, persiapan pengelasan (meliputi: pemilihan mesin las, penunjukan juru las, pemilihan elektroda, penggunaan jenis kampuh ${ }^{2}$.

Berdasarkan klasifikasi kerjanya proses pengelasannya dapat dibagi dalam tiga kelompok yaitu pengelasan cair, pengelasan tekan dan pematrian. Namun proses pengelasan yang paling banyak digunakan adalah pengelasan cair dengan busur Shielding Metal Arc Welding $(S M A W)$ dan gas. Proses ini juga tergantung dari material yang akan dilas,tidak semua logam memiliki sifat mampu las yang baik. Bahan yang mempunyai sifat mampu las yang baik diantaranya adalah baja paduan rendah. Baja ini dapat dilas dengan las busur elektroda terbungkus, las busur rendam dan las Metal Inert Gas (MIG). Mutu pengelasan tergantung dari pengerjaan dan proses pengelasan. Secara umum pengelasan dapat diartikan sebagai suatu ikatan metalurgi pada sambungan logam atau logam paduan yang dilaksanakan saat logam dalam keadaan cair. Variabel yang diteliti diantaranya: Variasi arus listrik, diameter elektroda, cacat las, metalurgi sambungan, kekerasan dan kekuatan konstruksi pengelasan ${ }^{3}$.

Mesin las SMAW menurut arusnya dibedakan menjadi tiga macam yaitu mesin las arus searah atau Direct Current (DC), mesin las arus bolakbalik atau Alternating Current (AC) dan mesin las arus ganda yang merupakan mesin las yang dapat digunakan untuk pengelasan dengan arus searah (DC) dan pengelasan dengan arus bolak-balik (AC). Mesin Las arus DC dapat digunakan dengan dua cara yaitu polaritas lurus dan polaritas terbalik. Mesin las DC polaritas lurus (DC-) digunakan bila titik cair bahan induk tinggi dan kapasitas besar, untuk pemegang elektrodanya dihubungkan dengan kutub negatif dan logam induk dihubungkan dengan kutub positif, sedangkan untuk mesin las DC polaritas terbalik (DC+) digunakan bila titik cair bahan induk rendah dan kapasitas kecil, untuk pemegang elektrodanya dihubungkan dengan kutub positif dan logam induk dihubungkan dengan kutub negative ${ }^{4}$.

Menurut penelitian Inggil Katulistiwa dan Yunus (2014) Pengaruh variasi besaran arus pengelasan dan jenis elektroda las tig (TUNGSTEN INNERT GAS) pada baja karbon rendah terhadap kekuatan tarik dan banding menunjukan bahwa nilai kekuatan tarik untuk baja paduan rendah dengan elektroda tungsten EWTh-2 menggunakan arus 90A adalah sebesar $366 \mathrm{MPa}$. Arus 110A sebesar 371,3 $\mathrm{MPa}$. Arus 130A sebesar 382,7 MPa. Untuk nilai kekuatan tarik untuk baja paduan rendah dengan elektroda EWP menggunakan arus 90A sebesar 372,1 MPa. Arus 110A sebesar 367,1 MPa. Arus 130A sebesar 374,3 MPa. Nilai kekuatan tarik dan tegangan luluh untuk spesimen kualitas kekuatan tarik baja paduan rendah tertinggi pengelasan TIG baik menggunakan elektroda tungsten Ewth-2 maupun menggunakan elektroda EWP adalah kelompok arus 130A. Tetapi di antara kedua kelompok arus tersebut pengelasan TIG yang menggunakan elektroda tungsten Ewth2 mempunyai hasil kekuatan tarik lebih 
besar yaitu 382,7 MPa dibandingkan dengan pengelasan TIG menggunakan elektroda tungsten EWP yaitu 374,3 $\mathrm{MPa}^{5}$.

Menurut peneltian Ma'ruf (2013) bahwa hasil penelitian disimpulkan besar arus berpengaruh terhadap kekerasan hasil pengelasan baja ST 60 menggunakan pengelasan SMAW. Kekerasan logam las tertinggi pada arus 90 A dengan nilai kekerasan sebesar 89,0 HRB, pada daerah HAZ kekerasan tertinggi pada arus 90 A dengan nilai kekerasan sebesar 90, 93 HRB dan kekerasan tertinggi logam induk pada arus 70 A dengan nilai kekerasan sebesar 92,81 HRB.

\section{METODE PENELITIAN}

a) Proses Pengujian

Bahan-bahan yang digunakan pada penelitian ini adalah plat baja karbon rendah dan elektroda E 6013 berdiameter $2,6 \mathrm{~mm}$, sedangkan alat yang digunakan adalah mesin las SMAW, mesin uji tarik. Penelitian ini dilakukan dengan menguji kekuatan tarik pada baja karbon rendah yang sudah di las dengan variasi ampere yang berbeda dengan tujuan untuk mengetahui hasil dari kekuatan tarik dan kekerasan pada baja karbon rendah dengan variasi amper pengelasan yang berbeda-beda.

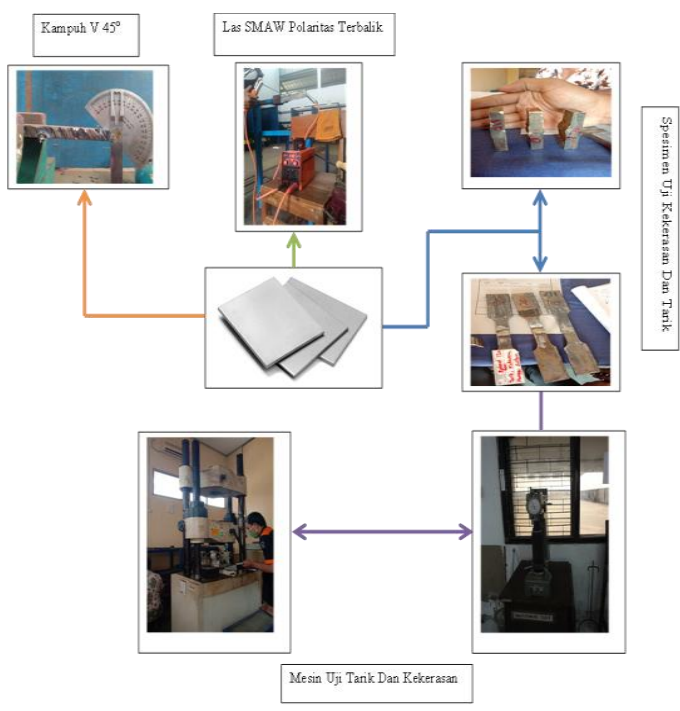

Gambar 1. Skema Penelitian b) Alat dan Bahan

1) Alat Penelitian

Tabel 1. Alat - alat

\begin{tabular}{|c|c|}
\hline Alat & Spesifikasi \\
\hline Trafo inverter & 250 ampere \\
\hline $\begin{array}{l}\text { Alat pengujian } \\
\text { tarik }\end{array}$ & $\begin{array}{l}\text { Standar JIS Z } \\
2241: 2011\end{array}$ \\
\hline $\begin{array}{l}\text { Alat pengujian } \\
\text { kekerasan } \\
\text { metode brinnel }\end{array}$ & $\begin{array}{l}\text { Standar JIS Z } \\
2245: 2011\end{array}$ \\
\hline Gergaji besi & General \\
\hline Gerenda & Makita \\
\hline Penggaris siku & General \\
\hline $\begin{array}{l}\text { Peralatan } \\
\text { pengelasan }\end{array}$ & $\begin{array}{l}\text { Kabel } \\
\text { elektroda, } \\
\text { kabel massa } \\
\text { pemegang } \\
\text { elektroda dan } \\
\text { penjepit massa }\end{array}$ \\
\hline Penggaris & General \\
\hline Ragum & General \\
\hline Kikir & General \\
\hline Kaca mata & General \\
\hline $\begin{array}{l}\text { Penggaris } \\
\text { sudut }\end{array}$ & General \\
\hline Palu besi & General \\
\hline Tang & General \\
\hline $\begin{array}{l}\text { Alat K3 } \\
\text { pengelasan }\end{array}$ & $\begin{array}{l}\text { Sarung tangan, } \\
\text { sepatu safety, } \\
\text { helm las dan } \\
\text { apron. }\end{array}$ \\
\hline
\end{tabular}

2) Bahan Penelitian

Tabel 2. Bahan - bahan

\begin{tabular}{|l|lr|}
\hline \multicolumn{2}{|c|}{ Bahan } & \multicolumn{2}{|c|}{ Spesifikasi } \\
\hline plat baja & ketebalan plat \\
karbon rendah & $10,41 \quad$ mm, \\
dengan & Kampuh yang \\
paduan rendah & digunakan jenis \\
& kampuh r V \\
& terbuka, tinggi \\
& akar 2 mm dan \\
\hline
\end{tabular}




\begin{tabular}{|l|l|}
\hline & $\begin{array}{l}\text { sudut kampuh } \\
\text { 90 derajat. }\end{array}$ \\
\hline Elektroda & E6013 dengan \\
& diameter 2,6 \\
mm.
\end{tabular}

\section{WAKTU DAN TEMPAT}

\section{PENELITIAN}

Adapun tempat pelaksanaannya adalah sebagai berikut:

1. Proses pembuatan kampuh dan Proses Pengelasan dilakukan di laboratorium Fakultas Teknik Mesin Universitas Muhammadiyah

Pekajangan Pekalongan Jl. Pahlawan No. 10 Gejlig - Kec. Kajen Kab. Pekalongan dan

2. Pembuatan bentuk dan pengujian spesimen benda uji dilakukan di laboratorium UPDT Lembaga Industri Tegal Jl. Raya Dampyak KM.4 Kompleks Industri Kecil Kabupaten Tegal

c) Variabel Penelitian

Dalam pengujian kekuatan tarik yang penulis laksanakan ada beberapa variable-variabel yang harus diamati dalam melakukan penelitian. Adapun variable yang diamati yaitu sebagai berikut:

a.Variabel Bebas.

1.Kuat arus.

b.Variabel Terikat.

1.Nilai kekerasan hasil pengelasan.

2.Nilai kekuatan tarik hasil pengelasan.

3.Nilai hasil uji bahan atau uji komposisi. d) Diagram Alir Penelitian

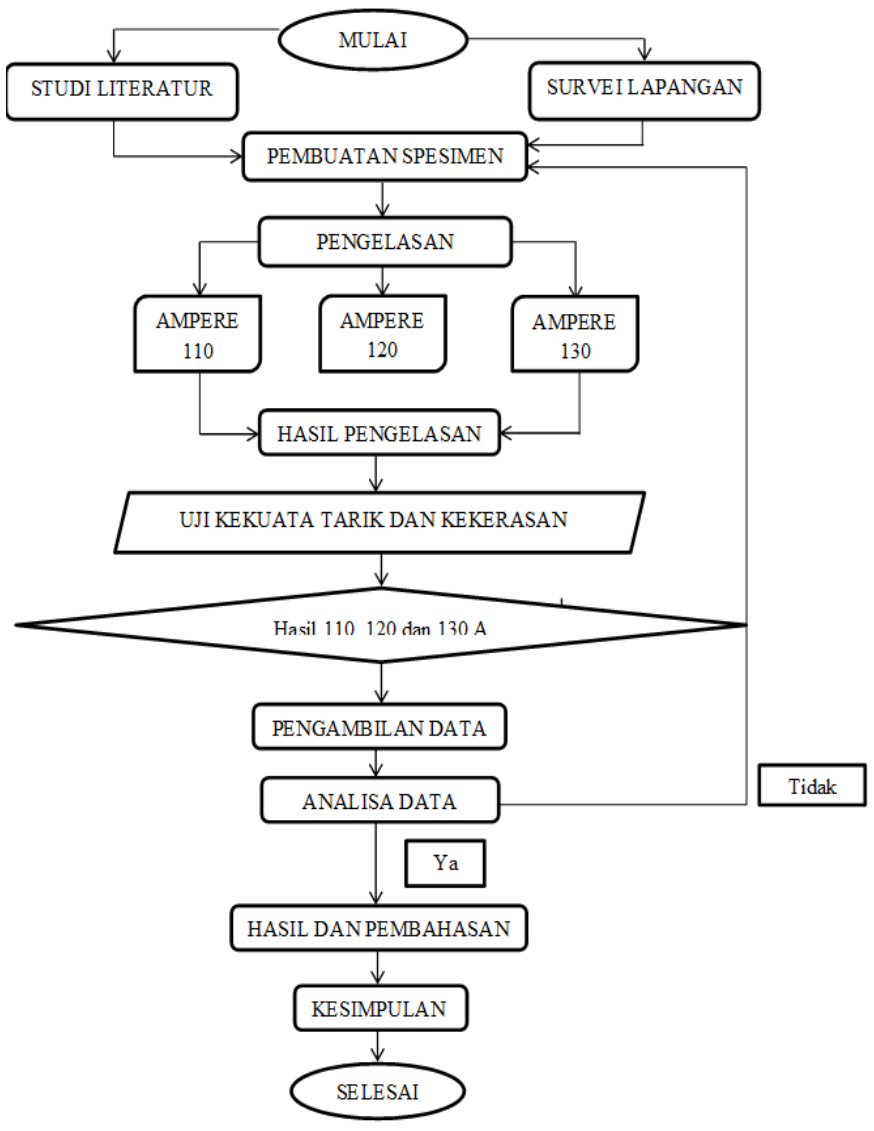

Tabel 1. Hasil pengujian tarik pada baja karbon rendah dengan pengelasan arus 110 A yang diterapkan pada 3 spesimen uji.

\begin{tabular}{|c|c|c|c|c|}
\hline No. & $\begin{array}{c}\text { Kode } \\
\text { Sampel }\end{array}$ & Parameter Uji & Satuan & Hasil Uji \\
\hline \multirow{5}{*}{1.} & \multirow{5}{*}{99.1} & Tebal x Lebar & $\mathrm{mm}$ & $10,50 \times 25,00$ \\
\hline & & Kuat Tarik & $\mathrm{N} / \mathrm{mm}^{2}$ & 415,24 \\
\hline & & Kuat Luluh & $\mathrm{N} / \mathrm{mm}^{2}$ & 271,19 \\
\hline & & Regangan & $\%$ & 27,6 \\
\hline & & Keterangan & . & Putus di luar las \\
\hline \multirow{5}{*}{2.} & \multirow{5}{*}{99.2} & Tebal x Lebar & $\mathrm{mm}$ & $10,40 \times 25,42$ \\
\hline & & Kuat Tarik & $\mathrm{N} / \mathrm{mm}^{2}$ & 413,25 \\
\hline & & Kuat Luluh & $\mathrm{N} / \mathrm{mm}^{2}$ & 251,42 \\
\hline & & Regangan & $\%$ & 31,64 \\
\hline & & Keterangan & . & Putus di luar las \\
\hline \multirow{5}{*}{3.} & \multirow{5}{*}{99.3} & Tebal x Lebar & $\mathrm{mm}$ & $10,39 \times 25,61$ \\
\hline & & Kuat Tarik & $\mathrm{N} / \mathrm{mm}^{2}$ & 412,81 \\
\hline & & Kuat Luluh & $\mathrm{N} / \mathrm{mm}^{2}$ & 323,08 \\
\hline & & Regangan & $\%$ & 32,28 \\
\hline & & Keterangan & . & Putus di luar las \\
\hline
\end{tabular}




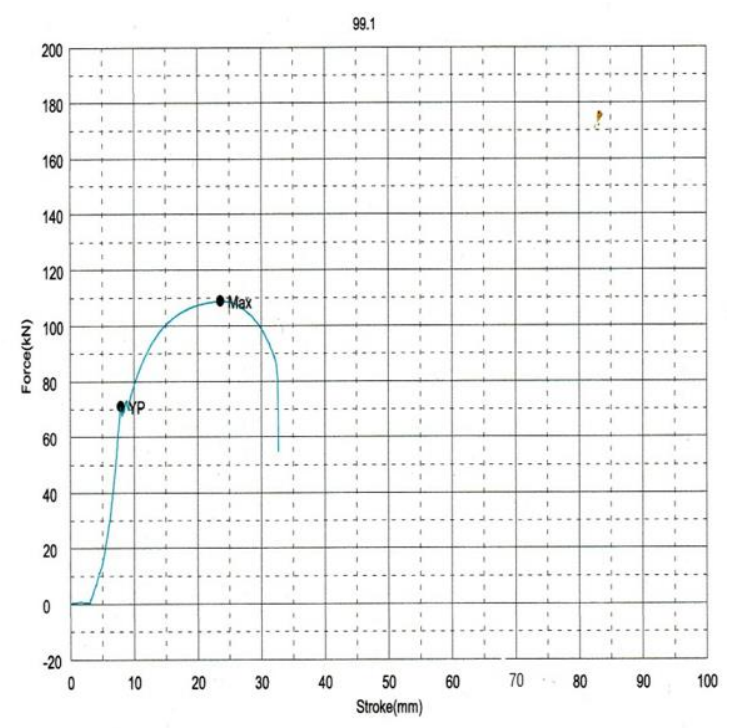

Gambar 18. Diagram kode sempel 110 A. 1

Max_Force : $109 \mathrm{Kn}$

Max_Stress : $415,238 \mathrm{~N} / \mathrm{mm}^{2}$

YP_Force : $71,1875 \mathrm{Kn}$

YP_Stress :271,190 N/mm²

Nilai kekuatan tarik untuk kelompok 110 A.1 adalah 415,238 Mpa atau $\mathrm{N} / \mathrm{mm}^{2}$. Di mana nilai tersebut di peroleh dari kalibrasi rumus yang sudah dimasukan ke dalam komputer pada pengujian kekuatan tarik. Pada diagram di atas ketika titik 0 diberi beban sampai pada $40 \quad \mathrm{kN}$ kemudian beban dihilangkan, maka bahan tersebut akan kembali ke kondisi semula (tepatnya hampir kembali semula) dikarenakan ada hukum hooke yang artinya untuk hampir semua logam, pada saat awal uji tarik, hubungan antara beban atau gaya yang diberikan berbanding lurus dengan perubahan panjang bahan tersebut. Tetapi bila beban ditarik sampai melewati titik $40 \mathrm{kN}$ dan berlanjut sampai titik YP ( Batas elastis), maka hukum hooke sudah tidak berlaku dan terdapat perubahan permanen dari bahan, dan proses pada penjelasan di atas di sebut deformasi elastis yang artinya bahan mulai melentur. Kemudian berlanjut lagi dari titik YP menuju ke titik Max itu terjadi proses deformasi plastis yaitu perubahan bentuk yang tidak kembali keadaan semula. Sebelum terjadinya deformasi plastis di situ terdapat landing yang artinya adanya regangan luluh sebelum memasuki deformasi plastis.Ketika diagram di atas sudah mancapai titik max maka dapat diartikan bahwa bahan sudah patah karena beban tarik sampai di titik maksimum penariakan. Pada diagram di atas dari titik max garis mulai menurun di karenakan sudah tidak adanya beban tarik karena bahan sudah patah.

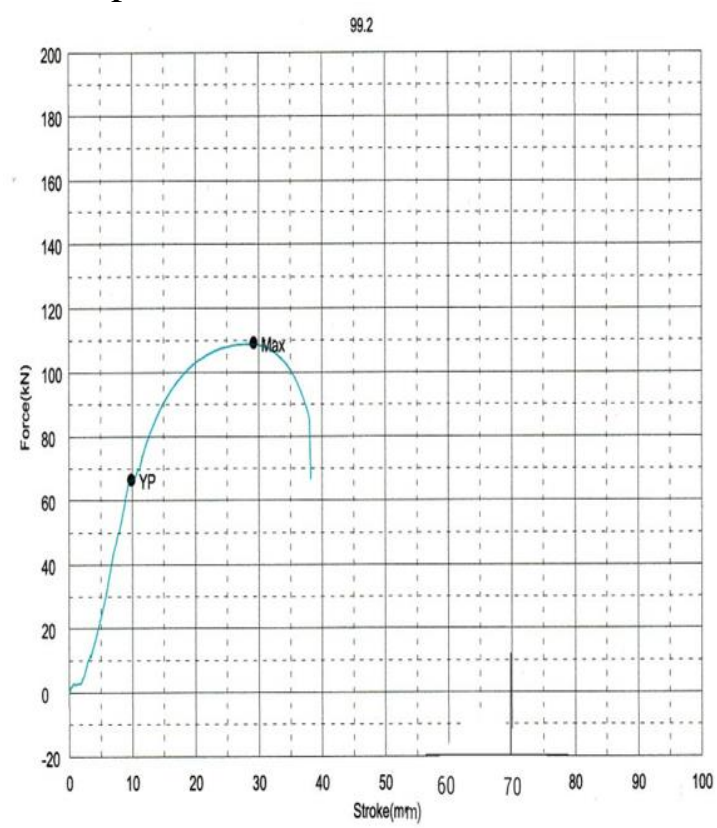

Gambar 19. Diagram kode sample 110 A. 2

Max_Force : 109,250 Kn

Max_Stress : 413,250 N/mm²

YP_Force : $66,4688 \mathrm{Kn}$

YP_Stress : $251,425 \mathrm{~N} / \mathrm{mm}^{2}$

Nilai kekuatan tarik untuk kelompok 110 A.2 adalah 413,250 Mpa atau $\mathrm{N} / \mathrm{mm}^{2}$.Di mana nilai tersebut di peroleh dari kalibrasi rumus yang sudah dimasukan ke dalam komputer pada pengujian kekuatan tarik. Pada diagram di atas ketika titik 0 diberi beban sampai pada $40 \quad \mathrm{kN}$ kemudian beban dihilangkan, maka bahan tersebut akan kembali ke kondisi semula (tepatnya hampir kembali semula) dikarenakan ada hukum hooke yang artinya untuk hampir semua logam, pada saat awal uji tarik, hubungan antara beban atau gaya yang diberikan berbanding lurus dengan perubahan panjang bahan tersebut. 
Tetapi bila beban ditarik sampai melewati titik $40 \mathrm{kN}$ dan berlanjut sampai titik YP ( Batas elastis ), maka hukum hooke sudah tidak berlaku dan terdapat perubahan permanen dari bahan, dan proses pada penjelasan di atas di sebut deformasi elastis yang artinya bahan mulai melentur. Kemudian berlanjut lagi dari titik YP menuju ke titik Max itu terjadi proses deformasi plastis yaitu perubahan bentuk yang tidak kembali keadaan semula. Sebelum terjadinya deformasi plastis di situ terdapat sedikit landing yang artinya adanya sedikit regangan luluh sebelum memasuki deformasi plastis.Ketika diagram di atas sudah mancapai titik max maka dapat diartikan bahwa bahan sudah patah karena beban tarik sampai di titik maksimum penariakan. Pada diagram di atas dari titik max garis mulai menurun di karenakan sudah tidak adanya beban tarik karena bahan sudah patah.

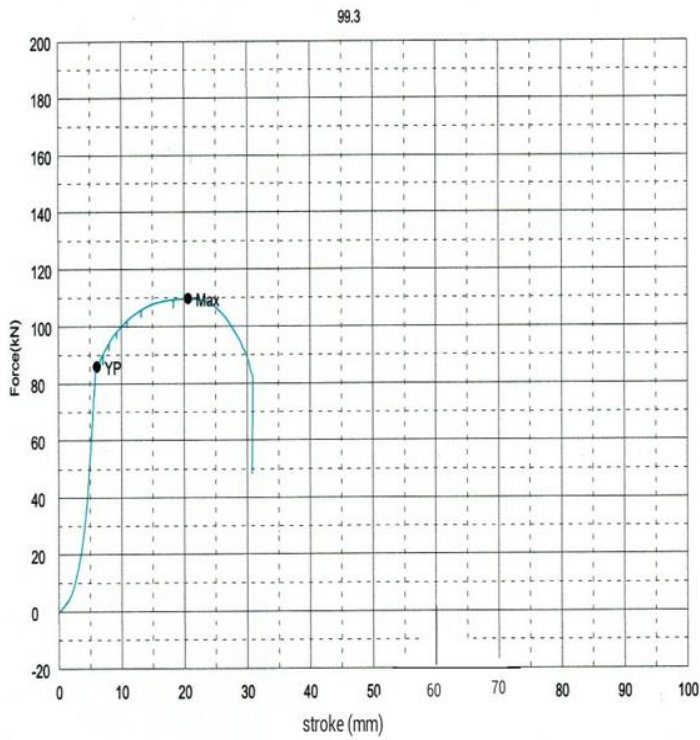

Gambar 20. Diagram kode sample 110 A. 3

Max_Force : $109,844 \mathrm{Kn}$

Max_Stress : $412,810 \mathrm{~N} / \mathrm{mm}^{2}$

YP_Force : $85,9688 \mathrm{Kn}$

YP_Stress :323,084 N/mm²

Nilai kekuatan tarik untuk kelompok 110 A. 3 adalah $412,810 \mathrm{Mpa}$ atau $\mathrm{N} / \mathrm{mm} 2$.Di mana nilai tersebut di peroleh dari kalibrasi rumus yang sudah dimasukan ke dalam komputer pada pengujian kekuatan tarik. Pada diagram di atas ketika titik 0 diberi beban sampai pada $40 \mathrm{kN}$ kemudian beban dihilangkan, maka bahan tersebut akan kembali ke kondisi semula (tepatnya hampir kembali semula) dikarenakan ada hukum hooke yang artinya untuk hampir semua logam, pada saat awal uji tarik, hubungan antara beban atau gaya yang diberikan berbanding lurus dengan perubahan panjang bahan tersebut. Tetapi bila beban ditarik sampai melewati titik $40 \mathrm{kN}$ dan berlanjut sampai titik YP (Batas Elastis), maka hukum hooke sudah tidak berlaku dan terdapat perubahan permanen dari bahan, dan proses pada penjelasan di atas di sebut deformasi elastis yang artinya bahan mulai melentur. Kemudian berlanjut lagi dari titik YP menuju ke titik Max itu terjadi proses deformasi plastis yaitu perubahan bentuk yang tidak kembali keadaan semula. Ketika diagram di atas sudah mancapai titik max maka dapat diartikan bahwa bahan sudah patah karena beban tarik sampai di titik maksimum penariakan. Pada diagram di atas dari titik max garis mulai menurun dikarenakan sudah tidak adanya beban tarik karena bahan sudah patah

Tabel 2. Hasil pengujian tarik pada baja karbon rendah dengan pengelasan arus 120 A yang diterapkan pada 3 spesimen uji.

\begin{tabular}{|c|c|c|c|c|}
\hline No. & $\begin{array}{c}\text { Kode } \\
\text { Sampel }\end{array}$ & Parameter Uji & Satuan & Hasil Uji \\
\hline \multirow{5}{*}{1.} & \multirow{5}{*}{99.4} & Tebal x Lebar & $\mathrm{mm}$ & $10,63 \times 25,59$ \\
\hline & & Kuat Tarik & $\mathrm{N} / \mathrm{mm}^{2}$ & 397,03 \\
\hline & & Kuat Luluh & $\mathrm{N} / \mathrm{mm}^{2}$ & 238,38 \\
\hline & & Regangan & $\%$ & 27,13 \\
\hline & & Keterangan & - & Putus di luar las \\
\hline \multirow{5}{*}{2.} & \multirow{5}{*}{99.5} & Tebal x Lebar & $\mathrm{mm}$ & $10,40 \times 25,57$ \\
\hline & & Kuat Tarik & $\mathrm{N} / \mathrm{mm}^{2}$ & 410,36 \\
\hline & & Kuat Luluh & $\mathrm{N} / \mathrm{mm}^{2}$ & 254,53 \\
\hline & & Regangan & $\%$ & 30,53 \\
\hline & & Keterangan & - & Putus di luar las \\
\hline \multirow{5}{*}{3.} & \multirow{5}{*}{99.6} & Tebal x Lebar & $\mathrm{mm}$ & $11,94 \times 25,23$ \\
\hline & & Kuat Tarik & $\mathrm{N} / \mathrm{mm}^{2}$ & 361,42 \\
\hline & & Kuat Luluh & $\mathrm{N} / \mathrm{mm}^{2}$ & 203,22 \\
\hline & & Regangan & $\%$ & 21,46 \\
\hline & & Keterangan & - & Putus di luar las \\
\hline
\end{tabular}




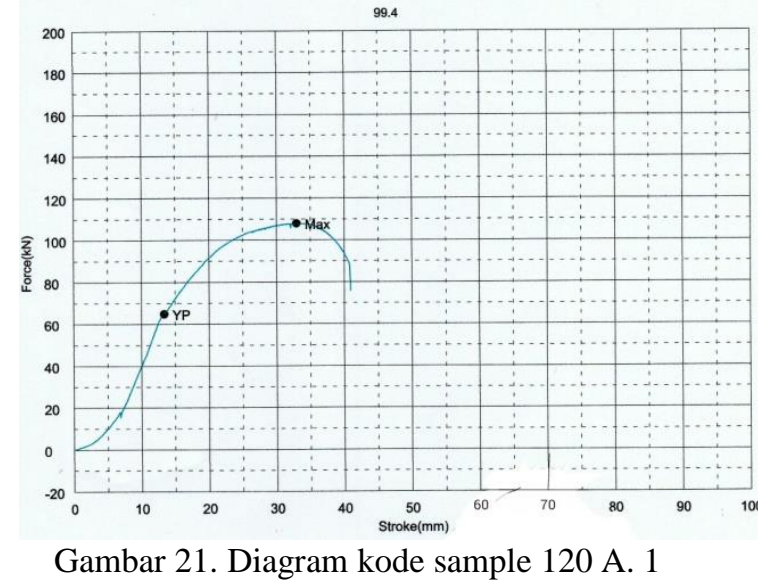

Max_Force : $108 \mathrm{Kn}$

Max_Stress : $397,027 \mathrm{~N} / \mathrm{mm}^{2}$

YP_Force : $64,8438 \mathrm{Kn}$

YP_Stress :238,377 N/mm ${ }^{2}$

Nilai kekuatan tarik untuk kelompok 120 A.1 adalah 397,027 Mpa atau N/mm2.Di mana nilai tersebut di peroleh dari kalibrasi rumus yang sudah dimasukan ke dalam komputer pada pengujian kekuatan tarik. Pada diagram di atas ketika titik 0 diberi beban sampai pada $40 \quad \mathrm{kN}$ kemudian beban dihilangkan, maka bahan tersebut akan kembali ke kondisi semula (tepatnya hampir kembali semula) dikarenakan ada hukum hooke yang artinya untuk hampir semua logam, pada saat awal uji tarik, hubungan antara beban atau gaya yang diberikan berbanding lurus dengan perubahan panjang bahan tersebut. Tetapi bila beban ditarik sampai melewati titik $40 \mathrm{kN}$ dan berlanjut sampai titik YP (Batas Elastis), maka hukum hooke sudah tidak berlaku dan terdapat perubahan permanen dari bahan, dan proses pada penjelasan di atas di sebut deformasi elastis yang artinya bahan mulai melentur. Kemudian berlanjut lagi dari titik YP menuju ke titik Max itu terjadi proses deformasi plastis yaitu perubahan bentuk yang tidak kembali keadaan semula. Ketika diagram di atas sudah mancapai titik max maka dapat diartikan bahwa bahan sudah patah karena beban tarik sampai di titik maksimum penariakan. Pada diagram di atas dari titik max garis mulai menurun di karenakan sudah tidak adanya beban tarik karena bahan sudah patah.

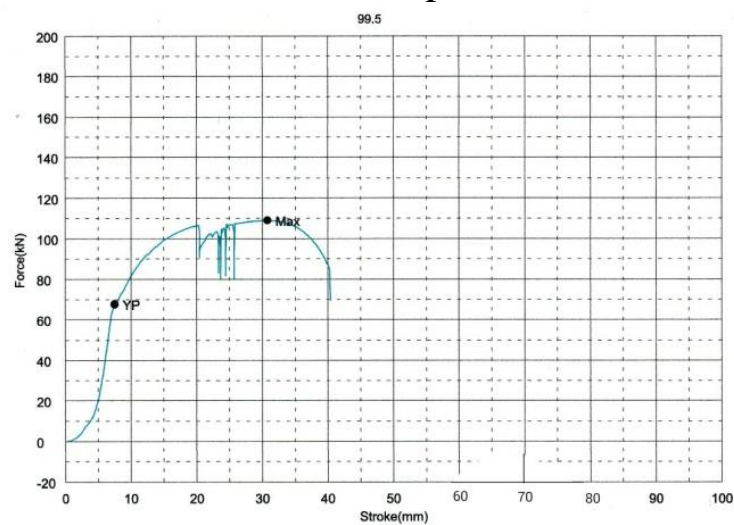

Gambar 22. Diagram kode sample 120 A. 2

Max_Force : $109,125 \mathrm{Kn}$

Max_Stress : $410,355 \mathrm{~N} / \mathrm{mm}^{2}$

YP_Force : $67,6875 \mathrm{Kn}$

YP_Stress :254,533 N/mm ${ }^{2}$

Nilai kekuatan tarik untuk kelompok 120 A.2 adalah 410,355 Mpa atau $\mathrm{N} / \mathrm{mm} 2$.Di mana nilai tersebut di peroleh dari kalibrasi rumus yang sudah dimasukan ke dalam komputer pada pengujian kekuatan tarik. Pada diagram di atas ketika titik 0 diberi beban sampai pada $40 \quad \mathrm{kN}$ kemudian beban dihilangkan, maka bahan tersebut akan kembali ke kondisi semula (tepatnya hampir kembali semula) dikarenakan ada hukum hooke yang artinya untuk hampir semua logam, pada saat awal uji tarik, hubungan antara beban atau gaya yang diberikan berbanding lurus dengan perubahan panjang bahan tersebut. Tetapi bila beban ditarik sampai melewati titik $40 \mathrm{kN}$ dan berlanjut sampai titik YP (Batas Elastis), maka hukum hooke sudah tidak berlaku dan terdapat perubahan permanen dari bahan, dan proses pada penjelasan di atas di sebut deformasi elastis yang artinya bahan mulai melentur. Kemudian berlanjut lagi dari titik YP menuju ke titik Max itu terjadi proses deformasi plastis yaitu perubahan bentuk yang tidak kembali keadaan semula. Saat terjadinya deformasi plastis di situ terdapat landing yang 
artinya adanya regangan luluh saat deformasi plastis terjadi. Ketika diagram di atas sudah mancapai titik max maka dapat diartikan bahwa bahan sudah patah karena beban tarik sampai di titik maksimum penariakan. Pada diagram di atas dari titik max garis mulai menurun di karenakan sudah tidak adanya beban tarik karena bahan sudah patah.

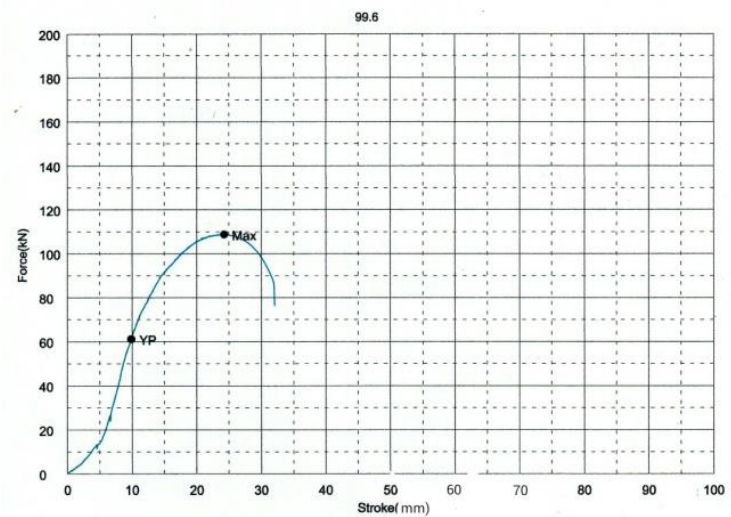

Gambar 23. Digram kode sample 120 A. 3

Max_Force : $108,875 \mathrm{Kn}$

Max_Stress : $361,415 \mathrm{~N} / \mathrm{mm}^{2}$

YP_Force : $61,2188 \mathrm{Kn}$

YP_Stress : 203,218 N/mm²

Nilai kekuatan tarik untuk kelompok 120 A.3 adalah 361,415 Mpa atau $\mathrm{N} / \mathrm{mm} 2$.Di mana nilai tersebut di peroleh dari kalibrasi rumus yang sudah dimasukan ke dalam komputer pada pengujian kekuatan tarik. Pada diagram di atas ketika titik 0 diberi beban sampai pada $40 \mathrm{kN}$ kemudian beban dihilangkan, maka bahan tersebut akan kembali ke kondisi semula (tepatnya hampir kembali semula) dikarenakan ada hukum hooke yang artinya untuk hampir semua logam, pada saat awal uji tarik, hubungan antara beban atau gaya yang diberikan berbanding lurus dengan perubahan panjang bahan tersebut. Tetapi bila beban ditarik sampai melewati titik $40 \mathrm{kN}$ dan berlanjut sampai titik YP (Batas Elastis), maka hukum hooke sudah tidak berlaku dan terdapat perubahan permanen dari bahan, dan proses pada penjelasan di atas di sebut deformasi elastis yang artinya bahan mulai melentur. Kemudian berlanjut lagi dari titik YP menuju ke titik Max itu terjadi proses deformasi plastis yaitu perubahan bentuk yang tidak kembali keadaan semula. Ketika diagram di atas sudah mancapai titik max maka dapat diartikan bahwa bahan sudah patah karena beban tarik sampai di titik maksimum penariakan. Pada diagram di atas dari titik max garis mulai menurun di karenakan sudah tidak adanya beban tarik karena bahan sudah patah.

Tabel 3. Hasil pengujian tarik pada baja karbon rendah dengan pengelasan arus 130 A yang diterapkan pada 3 spesimen uji.

\begin{tabular}{|c|c|c|c|c|}
\hline No. & $\begin{array}{c}\text { Kode } \\
\text { Sampel }\end{array}$ & Parameter Uji & Satuan & Hasil Uji \\
\hline \multirow{5}{*}{1.} & \multirow{5}{*}{99.7} & Tebal x Lebar & $\mathrm{mm}$ & $10,53 \times 25,67$ \\
\hline & & \begin{tabular}{|l|} 
Kuat Tarik \\
\end{tabular} & $\mathrm{N} / \mathrm{mm}^{2}$ & 408,68 \\
\hline & & Kuat Luluh & $\mathrm{N} / \mathrm{mm}^{2}$ & 254,23 \\
\hline & & Regangan & $\%$ & 30,84 \\
\hline & & Keterangan & - & Putus di luar las \\
\hline \multirow{5}{*}{2.} & \multirow{5}{*}{99.8} & \begin{tabular}{|l|} 
Tebal $x$ Lebar \\
\end{tabular} & $\mathrm{mm}$ & $10,16 \times 25,56$ \\
\hline & & \begin{tabular}{|l} 
Kuat Tarik \\
\end{tabular} & $\mathrm{N} / \mathrm{mm}^{2}$ & 422,98 \\
\hline & & \begin{tabular}{|l} 
Kuat Luluh \\
\end{tabular} & $\mathrm{N} / \mathrm{mm}^{2}$ & 249,82 \\
\hline & & \begin{tabular}{|l|} 
Regangan \\
\end{tabular} & $\%$ & 31,03 \\
\hline & & Keterangan & - & Putus di luar las \\
\hline \multirow{5}{*}{3.} & \multirow{5}{*}{99.9} & \begin{tabular}{|l|} 
Tebal x Lebar \\
\end{tabular} & $\mathrm{mm}$ & $10,38 \times 25,01$ \\
\hline & & Kuat Tarik & $\mathrm{N} / \mathrm{mm}^{2}$ & 413,85 \\
\hline & & Kuat Luluh & $\mathrm{N} / \mathrm{mm}^{2}$ & 269,64 \\
\hline & & Regangan & $\%$ & 30,24 \\
\hline & & Keterangan & - & Putus di luar las \\
\hline
\end{tabular}

99.7

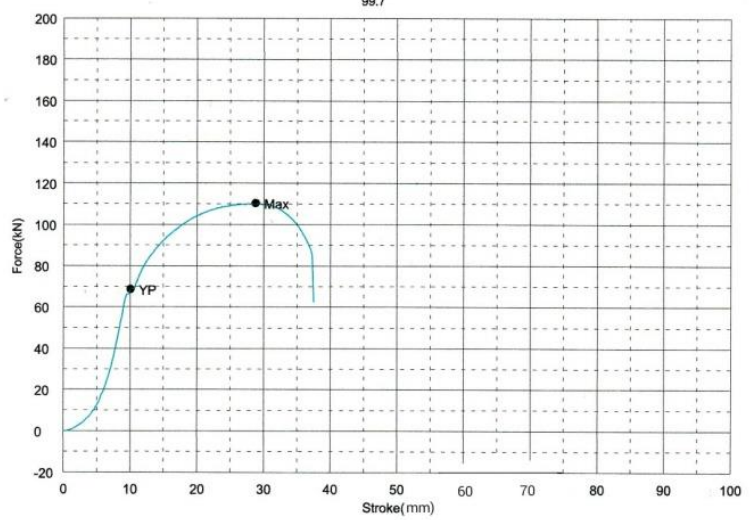

Gambar 24. Digram kode sample 130 A. 1

Max_Force : $110,469 \mathrm{Kn}$

Max_Stress : 408,682 N/mm²

YP_Force : $68,7188 \mathrm{Kn}$

YP_Stress : $254,227 \mathrm{~N} / \mathrm{mm}^{2}$

Nilai kekuatan tarik untuk kelompok 130 A. 1 adalah 408,68 Mpa atau $\mathrm{N} / \mathrm{mm} 2$. Di mana nilai tersebut di peroleh dari kalibrasi rumus yang sudah 
dimasukan ke dalam komputer pada pengujian kekuatan tarik. Pada diagram di atas ketika titik 0 diberi beban sampai pada $40 \mathrm{kN}$ kemudian beban dihilangkan, maka bahan tersebut akan kembali ke kondisi semula (tepatnya hampir kembali semula) dikarenakan ada hukum hooke yang artinya untuk hampir semua logam, pada saat awal uji tarik, hubungan antara beban atau gaya yang diberikan berbanding lurus dengan perubahan panjang bahan tersebut. Tetapi bila beban ditarik sampai melewati titik $40 \mathrm{kN}$ dan berlanjut sampai titik YP (Batas Elastis), maka hukum hooke sudah tidak berlaku dan terdapat perubahan permanen dari bahan, dan proses pada penjelasan di atas di sebut deformasi elastis yang artinya bahan mulai melentur. Kemudian berlanjut lagi dari titik YP menuju ke titik Max itu terjadi proses deformasi plastis yaitu perubahan bentuk yang tidak kembali keadaan semula. Ketika diagram di atas sudah mancapai titik max maka dapat diartikan bahwa bahan sudah patah karena beban tarik sampai di titik maksimum penariakan. Pada diagram di atas dari titik max garis mulai menurun di karenakan sudah tidak adanya beban tarik karena bahan sudah patah.

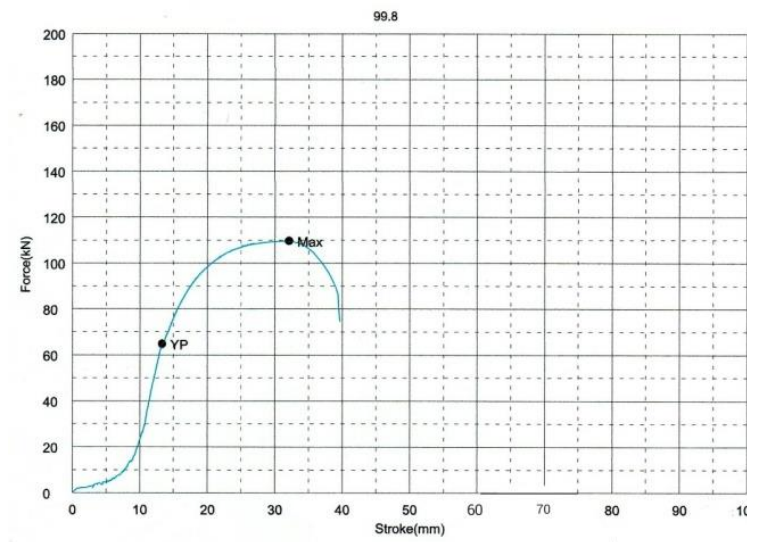

Gambar 25. Digram kode sample 130 A. 2

Max_Force : 109,844 Kn

Max_Stress : $422,981 \mathrm{~N} / \mathrm{mm}^{2}$

YP_Force : $64,8750 \mathrm{Kn}$

YP_Stress :249,817 N/mm ${ }^{2}$
Nilai kekuatan tarik untuk kelompok 130 A.2 adalah 422, 98 Mpa atau $\mathrm{N} / \mathrm{mm} 2$.Di mana nilai tersebut di peroleh dari kalibrasi rumus yang sudah dimasukan ke dalam komputer pada pengujian kekuatan tarik. Pada diagram di atas ketika titik 0 diberi beban sampai pada $40 \quad \mathrm{kN}$ kemudian beban dihilangkan, maka bahan tersebut akan kembali ke kondisi semula (tepatnya hampir kembali semula) dikarenakan ada hukum hooke yang artinya untuk hampir semua logam, pada saat awal uji tarik, hubungan antara beban atau gaya yang diberikan berbanding lurus dengan perubahan panjang bahan tersebut. Tetapi bila beban ditarik sampai melewati titik $40 \mathrm{kN}$ dan berlanjut sampai titik YP (Batas Elastis), maka hukum hooke sudah tidak berlaku dan terdapat perubahan permanen dari bahan, dan proses pada penjelasan di atas di sebut deformasi elastis yang artinya bahan mulai melentur. Kemudian berlanjut lagi dari titik YP menuju ke titik Max itu terjadi proses deformasi plastis yaitu perubahan bentuk yang tidak kembali keadaan semula. Ketika diagram di atas sudah mancapai titik max maka dapat diartikan bahwa bahan sudah patah karena beban tarik sampai di titik maksimum penariakan. Pada diagram di atas dari titik max garis mulai menurun di karenakan sudah tidak adanya beban tarik karena bahan sudah patah.

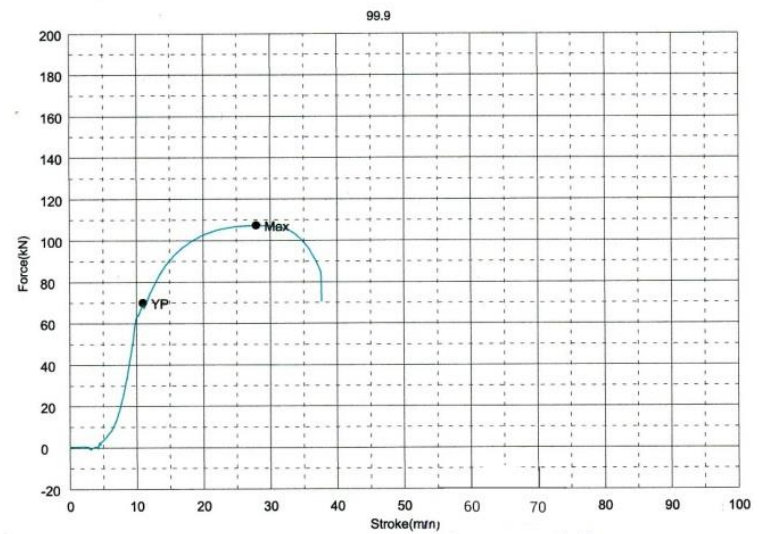

Gambar 26. Digram kode sample 130 A. 3 
Max_Force : $107,438 \mathrm{Kn}$

Max_Stress : 413,852 N/mm²

YP_Force : $70 \mathrm{Kn}$

YP_Stress : $269,642 \mathrm{~N} / \mathrm{mm}^{2}$

Nilai kekuatan tarik untuk kelompok 130 A.3 adalah 413,85 Mpa atau $\mathrm{N} / \mathrm{mm} 2$. Di mana nilai tersebut di peroleh dari kalibrasi rumus yang sudah dimasukan ke dalam komputer pada pengujian kekuatan tarik. Pada diagram di atas ketika titik 0 diberi beban sampai pada $40 \mathrm{kN}$ kemudian beban dihilangkan, maka bahan tersebut akan kembali ke kondisi semula (tepatnya hampir kembali semula) dikarenakan ada hukum hooke yang artinya untuk hampir semua logam, pada saat awal uji tarik, hubungan antara beban atau gaya yang diberikan berbanding lurus dengan perubahan panjang bahan tersebut. Tetapi bila beban ditarik sampai melewati titik $40 \mathrm{kN}$ dan berlanjut sampai titik YP (Batas Elastis), maka hukum hooke sudah tidak berlaku dan terdapat perubahan permanen dari bahan, dan proses pada penjelasan di atas di sebut deformasi elastis yang artinya bahan mulai melentur. Kemudian berlanjut lagi dari titik YP menuju ke titik Max itu terjadi proses deformasi plastis yaitu perubahan bentuk yang tidak kembali keadaan semula. Ketika diagram di atas sudah mancapai titik max maka dapat diartikan bahwa bahan sudah patah karena beban tarik sampai di titik maksimum penariakan. Pada diagram di atas dari titik max garis mulai menurun di karenakan sudah tidak adanya beban tarik karena bahan sudah patah.

\section{KESIMPULAN}

Dari hasil penelitian dapat disimpulkan bahwa ada pengaruh variasi arus pengelasan terhadap kekuatan mekanik sebagai berikut :

1. Dari hasil penelitian kekuatan tarik yang sudah di uji, bahwa kuat arus 110 amper mempunyai nilai ratarata sebesar 413,66 N/mm² sedangkan pada kuat arus 120 amper mempunyai nilai rata-rata sebesar $389 \mathrm{~N} / \mathrm{mm}^{2}$, dan kuat arus 130 amper mempunyai nilai ratarata sebesar $415,17 \quad \mathrm{~N} / \mathrm{mm}^{2}$. Disimpulkan bahwa kekuatan tarik tertinggi ber urutan diberikan oleh jenis variasi arus 130 amper, 110 amper dan 120 amper. Pada hasil tersebut diartikan bahwa tinggi rendahnya kuat arus pengelasan mempengaruhi kekuatan tarik suatu bahan yang sudah dilas dengan arus yang berbeda beda.

2. Dari hasil penelitian disimpulkan bahwa besar arus berpengaruh terhadap kekerasan hasil pengelasan baja karbon rendah menggunakan pengelasan SMAW. Kekerasan pada daerah logam induk tertinggi pada arus $110 \mathrm{~A}$ dengan nilai rata-rata kekerasan sebesar 205,22 HB, pada daerah lasan kekerasan tertinggi pada arus 120 dengan nilai rata-rata sebesar 183,52 HB dan pada daerah HAZ kekerasan tertinggi pada arus $120 \mathrm{~A}$ dengan nilai rata-rata kekerasan sebesar 168,65 HB.

\section{REFERENSI}

[1] M. A.S. and K. B.H., "Pengaruh Variasi Kecepatan Dan Kuat Arus Terhadap Kekerasan, Tegangan Tarik, Struktur Mikro Baja Karbon Rendah Dengan Elektroda E6013," Rekayasa Mesin, vol. 13, no. 1, pp. 1-8, 2013.

[2] Z. Muhsin, Suardy, and Suryadi, "Analisis Perbandingan Kualitas Las SMAW Kampuh V dengan Uji Bending pada Baja ST 37," Teknologi, vol. 19, pp. 45-56, 2018.

[3] H. S. Raharjo and R. Jp, "Variasi Arus Listrik Terhadap Sifat Mekanis Sambungan Las Shielding Metal Arc Welding ( 
Smaw )," Simp. Nas. RAPI x1 FT UMS, pp. 93-97, 2012.

[4] A. PUTRA, "Pengaruh Polaritas Pengelasan Dan Jenis Elektroda Terhadap Kekuatan Tarik Dan Ketangguhan Las Smaw (Shielded Metal Arc Welding)," J. Pendidik. Tek. Mesin UNESA, vol. 6, no. 01, p. 250958, 2017.

[5] K. Inggil and Yunus, "Pengaruh Variasi Besar Arus Pengelasan Dan Jenis Elektroda Las Tig (Tungsten Innert Gas) Pada Baja Karbon Rendah Terhadap Kekuatan Tarik Dan Bending," J. Tek. mesin, vol. 2, pp. 61-69, 2014.

[6] Ma'ruf, "Pengaruh Arus Terhadap Kekerasan Hasil Pengelasan Baja St 60 Menggunakan Pengelasan Smaw," Ekp, vol. 14, no. 3, pp. 211-218, 2013. 